\title{
Need for Quality Education and Research in India
}

\author{
P. K. Nagar ${ }^{1}$ and Shipra Nagar ${ }^{2 *}$ \\ ${ }^{1}$ Batuk Dham Colony, Kamachha, Varanasi, 221010, India \\ ${ }^{2}$ College of Home Science, Central Agricultural, University, Tura, Meghalaya, 794005, India \\ *Corresponding author
}

\section{A B S T R A C T}

\begin{tabular}{|l|}
\hline Ke y w o r d s \\
$\begin{array}{l}\text { Research, } \\
\text { Education, } \\
\text { Scientific } \\
\text { Environment }\end{array}$ \\
\hline Article Info \\
\hline $\begin{array}{l}\text { Accepted: } \\
07 \text { August } 2020 \\
\text { Available Online: } \\
\text { 10 September } 2020\end{array}$ \\
\hline
\end{tabular}

Education is a key to effective development for which the school experiences lays foundation for different learning styles that gives way to open the creative minds for research. Higher education plays an important role in this. Many renowned universities and Higher Educational Institutions like IITs, IIMs and IISc have their own importance in promoting higher education. Unfortunately due to various reasons, the system fails to attract the young scientists to make the country as a global power in education. The New Education policy has given a hope to reframe the whole system with introduction of different attractive schemes. This article gives a summarized view of the various steps to improve the quality of education and research in India.

\section{Introduction}

In a recent article Balakrishnan (2019) has advocated to make Indian universities as centers of research and innovation. He emphasized that a large section of Indian youth are benefited by these universities and most of the manpower are being provided by them. India's success stories in various scientific fields are possible only through manpower trained in universities and research institutions. He also advocated an urgent need to improve quality education and research in these institutions so that they can become really world class institutes.
The main purpose of education is to develop creativity in thinking and learning, enhancement of intellectual power and values, character development for progress of S\&T in the country and building national character. Experiences in the schools are one of the most important for children as it lays a profound impact on the learning styles of the future generation. Education is the birthright of every child but it is unfortunate that about more than 30 million children out of 200 million in the age group of 6-14 years are deprived of school education. Despite efforts from government through the 'Sarva Shiksha Abhiyan' and many other incentives given to 
rural families, many children dropout from schools which results in educational loss. To ensure that students remain enrolled, an enabling ecosystem needs to be developed that comprises of better infrastructure of schools, teachers who have a passion for their chosen vocation and pedagogy that transitions from rote learning to conceptual methods which can give the students to experiment and know the facts of science.

While school education can build a foundation for national development, higher education plays a pivotal role in shaping their destiny. India has the third largest education system in the world and produces $2.5 \mathrm{~m}$ graduates every year, yet most of them do not have the quality. If we fail to address the fundamental issues of higher education this 'demographic dividend' and 'youth bulge' will become a social and political nightmare. We take pride in having more youths in our population (nearly $21 \%$ according to Census 2011), but this demographic advantage will become a liability if we fail to address the fundamental issues of higher education. According to NAAC report, about $66 \%$ of our universities and about more than $75 \%$ of $\mathrm{PG}$ colleges are below the minimum level of educational acceptability. Sen (2015) has rightly pinpointed the pitfalls and remedies for Indian science education and research. But actually our education system has failed miserably in respect of creative thinking, enhancement of intellectual power, character development for progress of $\mathrm{S} \& \mathrm{~T}$ in the country and building national character. Institutions like IIMs, IITs and IISc have their own importance in higher education, but the vast majority of young youth must derive benefit from higher education. The fact is that the standard of higher education has deteriorated considerably and not up to the mark to attract the quality required for country to become global power in education. One of the main reasons for the decline is less emphasis on research and institutions which were intended to be research centers do little or no research with less encouragement towards interdisciplinary teaching and research. Grover (2019) has suggested that for an activity to be classified as research it has to be novel, creative, systematic, transferable and /or reproducible and its outcome should uncertainty. He further suggested simple categorization of research- academic research and post academic research and both have epistemic and use objectives (Grover, 2019). The boundary between academic and post academic research is not sharp but, rather there is a large overlap between the two.

The new Education Policy has given an excellent framework for Indian education to boost. For the first time, the education has been seen in a complete framework. It has been considered from primary to higher education. The only question here is about its implementation. If we do not get success on its implementation we would be a big loser. A correct step has been taken to establish one regulatory body to act as a watchdog. But it would be successful only when it is free from the web of red-tapism and nepotism. At present, there are more than one regulatory bodies and inspite of it many are not functioning properly causing held up in their quality. In higher education the goal for gross enrolment ratio has been put at $50 \%$ and for this we must spent $6 \%$ of our gross GDP on education system. The new education policy has also talked about new national research foundation though a good proposal but for this quality education and quality training cum quality teachers are important. It will help in boosting new research atmosphere which is free from prejudices, bureaucratic formalities, false propaganda, sycophancy, political maneuvering, etc. The plight of the increasing numbers of $\mathrm{Ph}$.Ds produced by our universities who struggle hard to find good placements is a glaring example of scientific 
'illness.' On the global scenario, we are much behind. Unfortunately, in the Indian scenario, heavy 'elitism' prevails and those occupying scientific managing posts continue short sightness policies over successive generation. It is high time we must try to bring back top Indian scientists working abroad to spend some time doing research and teaching in India.

Many of our institutions do not have proper healthy scientific environment causing frustration among budding scientists. A healthy scientific environment is one which is free from prejudices, bureaucratic formalities, dishonesty, false claims and propaganda, sycophancy and political maneuvering etc (Nagar, 2013). Big science atmosphere has gripped many Indian scientists, who think that doing research with small funds is beyond their dignity. Actually it is the quality of leadership, and the level of scientific honesty and transparency that is required for a breakthrough in Indian science. Small initiatives pave way for the bigger ones and thus the scientists at junior levels should be given encouragement in terms of promotions or monitory assistance in bringing even the small-funded innovative projects. This would definitely prove to be beneficial for them to build up a knowledge and scientific data repository. As pointed by Lavakare (2016) due to the lack of innovative ways of teaching science, the students are less interested in it, causing less numbers to opt for higher education system. A sound science education is the foundation on which strong nations are built and there is little doubt that the absence of truly exemplary institutions of learning, barring few, is terrible news for a nation that aspires to be a world leader. In an interesting article Jalote (2019) has emphasized that top research universities in India, which can possibly reach global ranking, need a substantially higher funding rather than those which focus in budget for research and even in higher more on only teaching. Unfortunately in many, little support exists in budget for research and even in Higher Educational Institutions (HEIs), $80 \%$ of it towards recurring expenses. It was suggested that to become top 200 HEIs some of them must be expanded substantially comparable in size globally and their support must be increased substantially. Ironically the biggest problem in many of these is a chronic shortage of quality and trained teachers who may not only efficient in teaching but also excel in research. In most of these more than $30 \%$ posts are vacant and the acute shortage of dedicated and qualified teachers can not be a real model or inspiration to youth. It is rightly pointed out that the abdication of responsibilities for early educational system weakens school learning, eventually weakening the universities itself (Subramianian, 2016). Our younger generation should get opportunities for an all round global education and training to keep them abreast with the global developments to take up the challenges of the era so that the country may become a leading power in the coming years. Policy makers must consider our historical, political and economical characters before formulating policies on improving quality education and research institution. To bring revolution in modern education and working condition in HEIs we must emphasize mainly on scientific education and research and basic changes are required in the system devoid of bureaucratic hindrances.

\section{References}

Balakrishnan, S. 2019. Current Science, 117: 1123-1124

Sen, S.K. 2015. Current Science, 108: 21522166

Grover, R.B. 2019. Current Science, 117: 1140-1147

Grover, R.B. 2019. Indian Journal of 
Historical Sciences, 54: 50-58

Nagar, P.K. 2013. Current Science, 104: 813

Lavakare, P.J. 2016. Current Science, 110: 10

Jalote, P. 2019. Current Science, 115: 1479-
1482

Subramanian, E.C. 2016. Current Science, 111: $131-132$

\section{How to cite this article:}

Nagar, P. K. and Shipra Nagar. 2020. Need for Quality Education and Research in India. Int.J.Curr.Microbiol.App.Sci. 9(09): 782-785. doi: https://doi.org/10.20546/ijcmas.2020.909.098 